\title{
The Association between Zinc and Copper and Cardiometabolic Risk Factors in Adults
}

\author{
Dana Alkudsi ${ }^{1}$, Sara Hamad ${ }^{1}$, Hanan Alkeldi ${ }^{1}$
}

Supervised by: Dr. Abdelhamid Kerkadi ${ }^{1}$, Dr. Abdelali Agouni ${ }^{2}$, Ms. Reem Salih ${ }^{1}$

${ }^{1}$ Human Nutrition Department, College of Health Sciences, Qatar University, Doha, Qatar

${ }^{2}$ Pharmaceutical Sciences Department, College of Pharmacy, Qatar University, Doha, Qatar

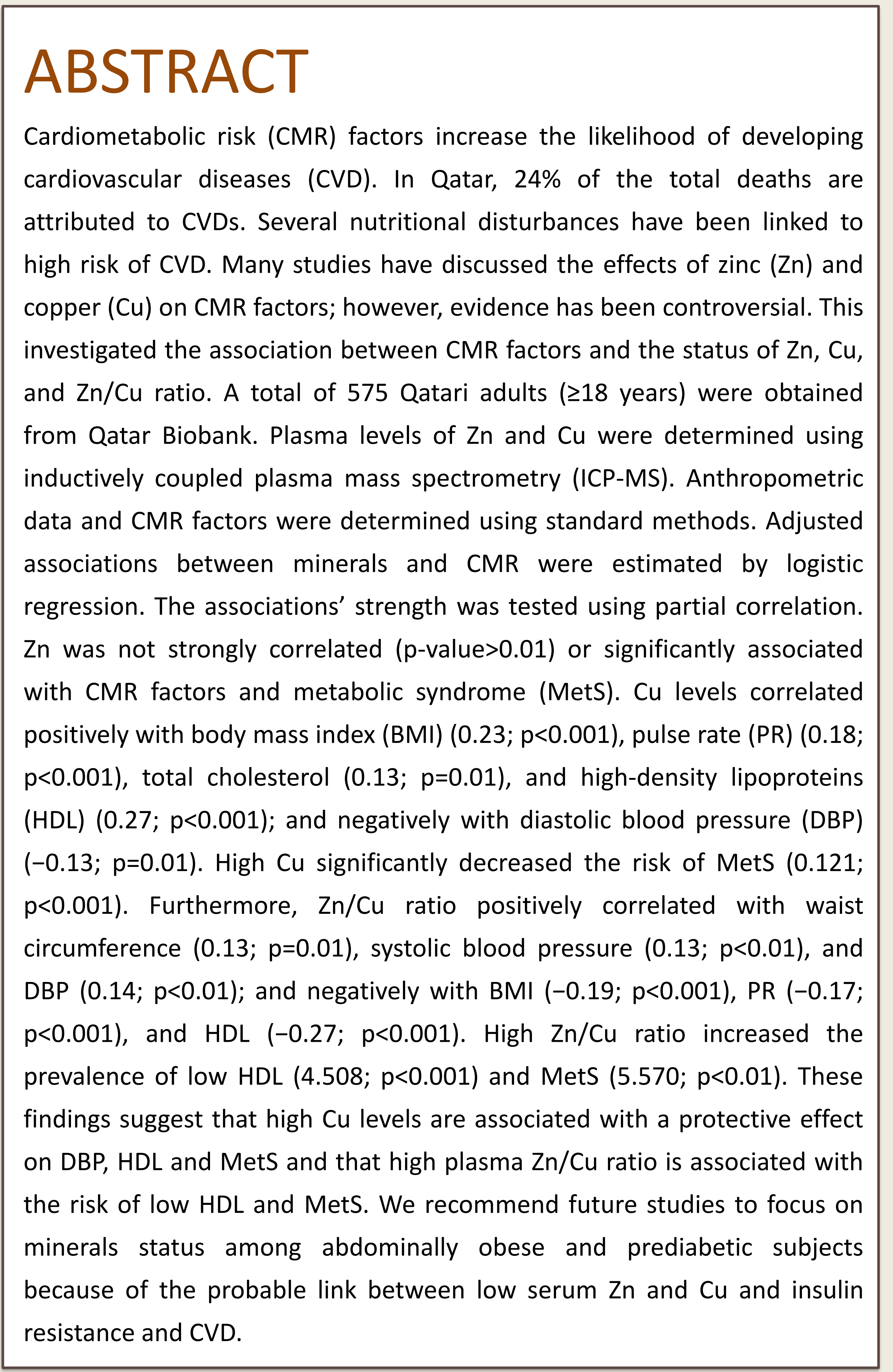

\section{INTRODUCTION}

CMR factors are factors that increase the likelihood of developing

$\mathrm{Zn}$ is a heavy metal known to suppress inflammation, reduce oxidative stress, and catalyze lipid metabolic enzymes. It is also used by muscle and fat cells to metabolize glucose and regulate insulin receptors synthesis. Moreover, $\mathrm{Zn}$ has a role in controlling blood pressure and vascular tune modulation.

Cu is an essential cofactor in numerous antioxidant and oxidoreductive enzymes which reduce atherosclerosis and inflammation and improve cardiovascular function and fat metabolism. Cu indirectly affects diabetes and blood pressure regulation.

- Many studies discussed the association between $\mathrm{Zn}, \mathrm{Cu}$ and CMR factors. In highlight of lipid profile, $\mathrm{Zn}$ relationship to lipid profile indicators is controversial ${ }^{1,2}$. On the other hand, plasma $\mathrm{Cu}$ was positively associated with high TC, HDL, and risk of dyslipidemia ${ }^{3}$. In addition, an inverse relationship was found between $\mathrm{Cu}: \mathrm{Zn}$ ratio and lipid profile ratios ${ }^{1}$.

$\mathrm{Zn}$ relationship with diabetes is not well established. $\mathrm{HbA1c}$ was found to be positively associated with plasma concentration of $\mathrm{Cu}$ and negatively with Zn:Cu ratio in type 2 diabetes ${ }^{4}$. Further, $\mathrm{Cu}$ and $\mathrm{Zn}$ intakes and $\mathrm{Cu}: \mathrm{Zn}$ ratio had no association with $\mathrm{HTN}^{5,6}$. However, a study showed that high Cu levels may elevate the susceptibility of $\mathrm{HTN}^{7}$.

\section{METHODOLOGY}

\section{Initial sample size= 575
Final sample size $=437$}

(1) Adult men and women aged $\geq 18$ years old

Qatari and residents, who have lived for $\geq 15$

Qatari and residen
years in Qatar

3 Fasting participants with data on $\mathrm{Zn}, \mathrm{Cu}$, and $\mathrm{CMR}$ factors (WC, BMI, lipid profile data, glucose, insulin, $\mathrm{Hb} 1 \mathrm{Ac}, \mathrm{SBP}, \mathrm{DBP}$, and PR)

Excluded: 1- diagnosed with diabetes, CVD, and HTN 2- taking mineral supplements or medications; 3- having pacemakers; 4- pregnant or lactating women

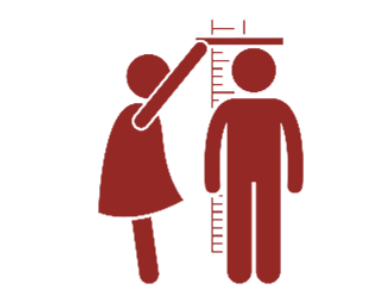

Wall mounted shoes on Wall mounted

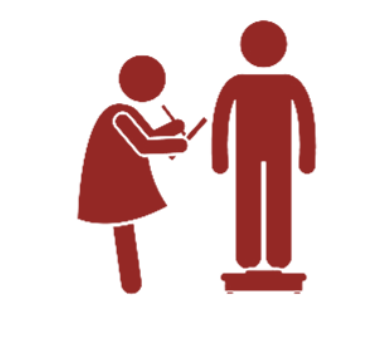

\section{Calibrated scale with} light clothes

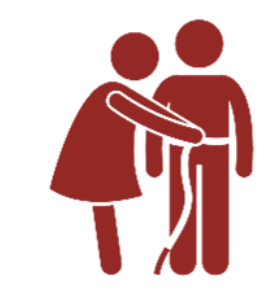
Measured at the level
of the umbilicus using of the umbilicus using

\section{RESULTS}

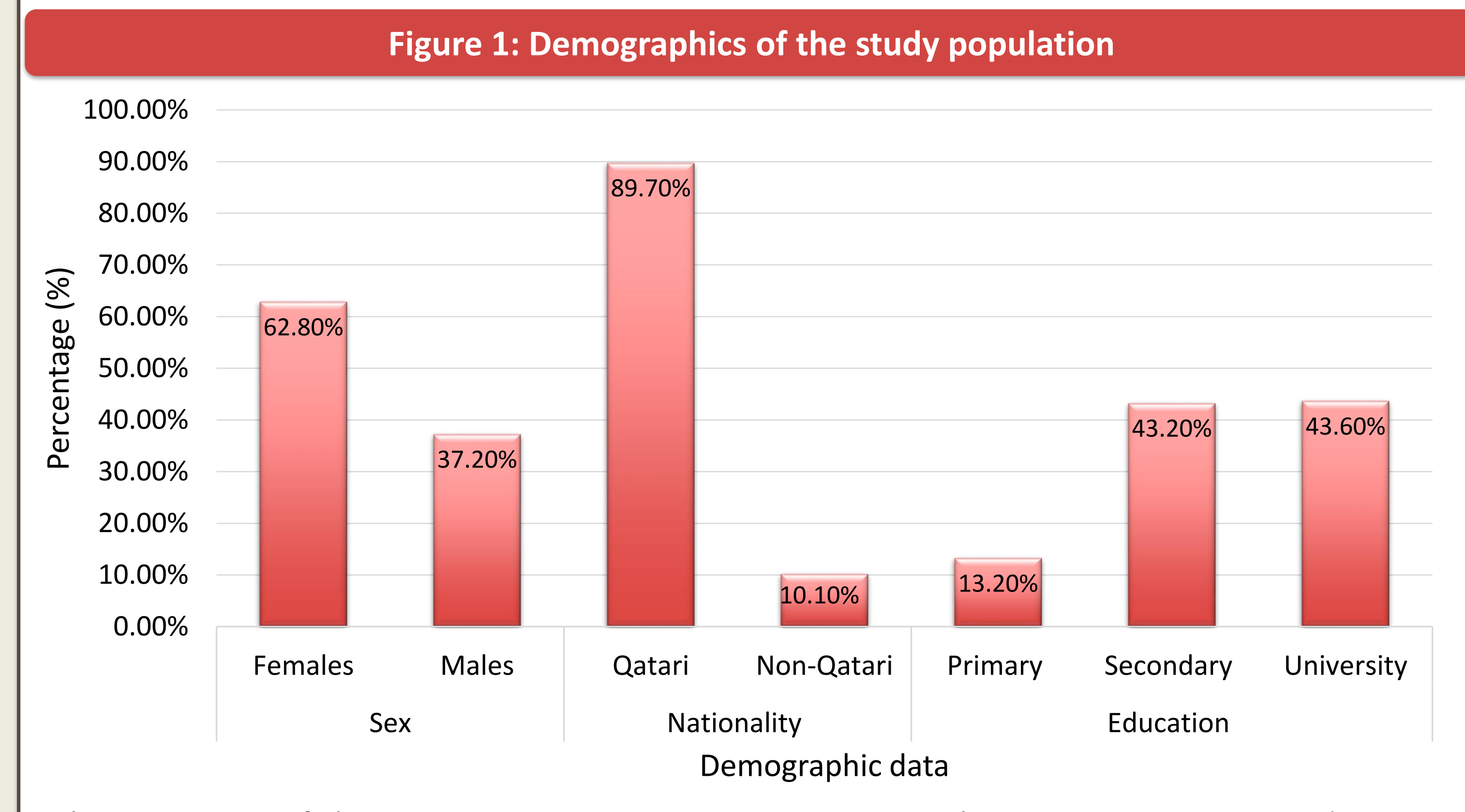

The mean age of the 437 participants was $41 \pm 12.6$ years. The mean serum zinc and copper levels were $12.6 \pm 2.0$ and $18.2 \pm 4.7 \mu \mathrm{mol} / \mathrm{L}$, respectively.

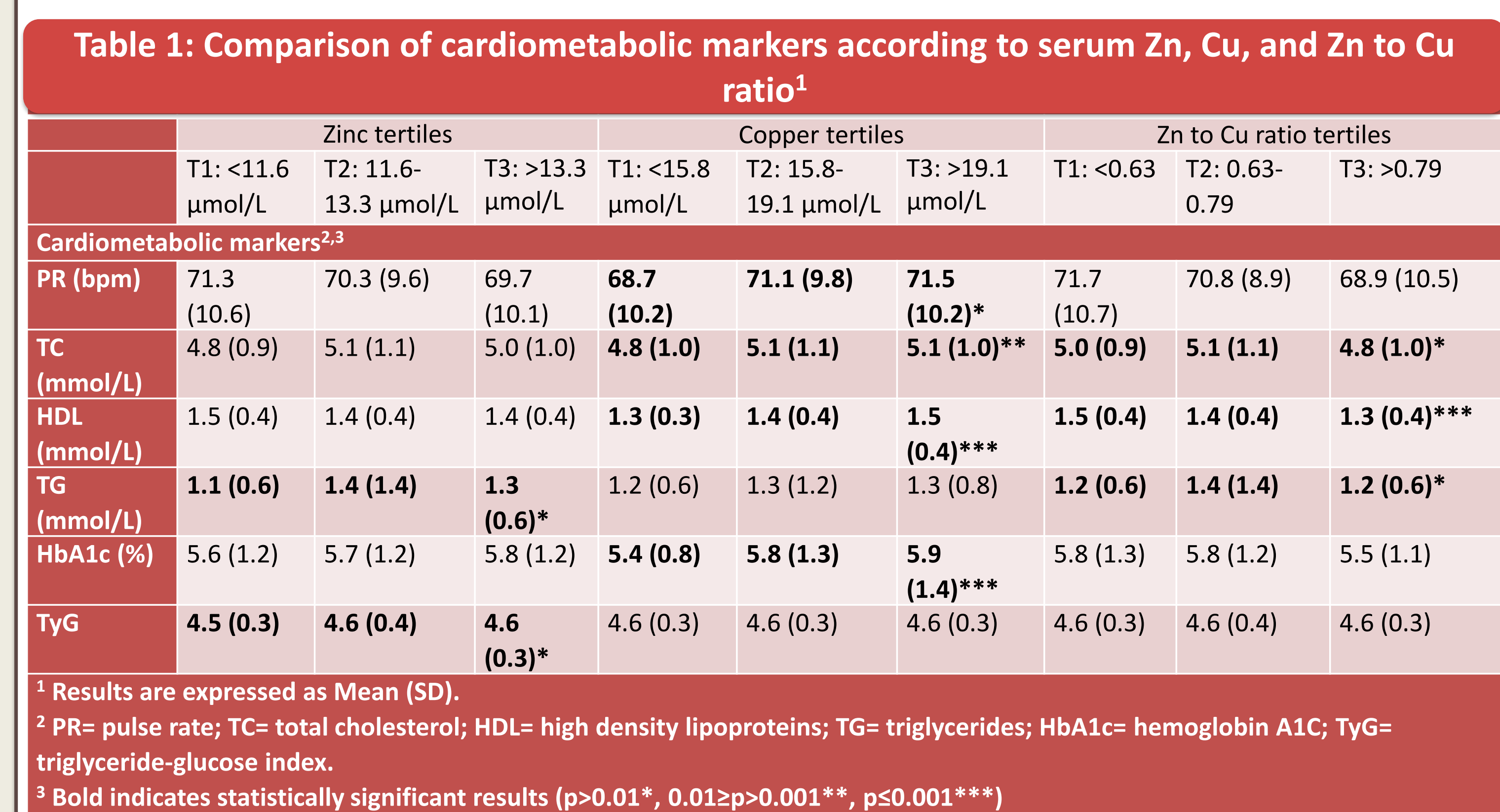

Other CMR factors were not significantly different across trace minerals tertiles (table 1). Figure 2: Partial Correlation between cardiometabolic indicators and trace minerals
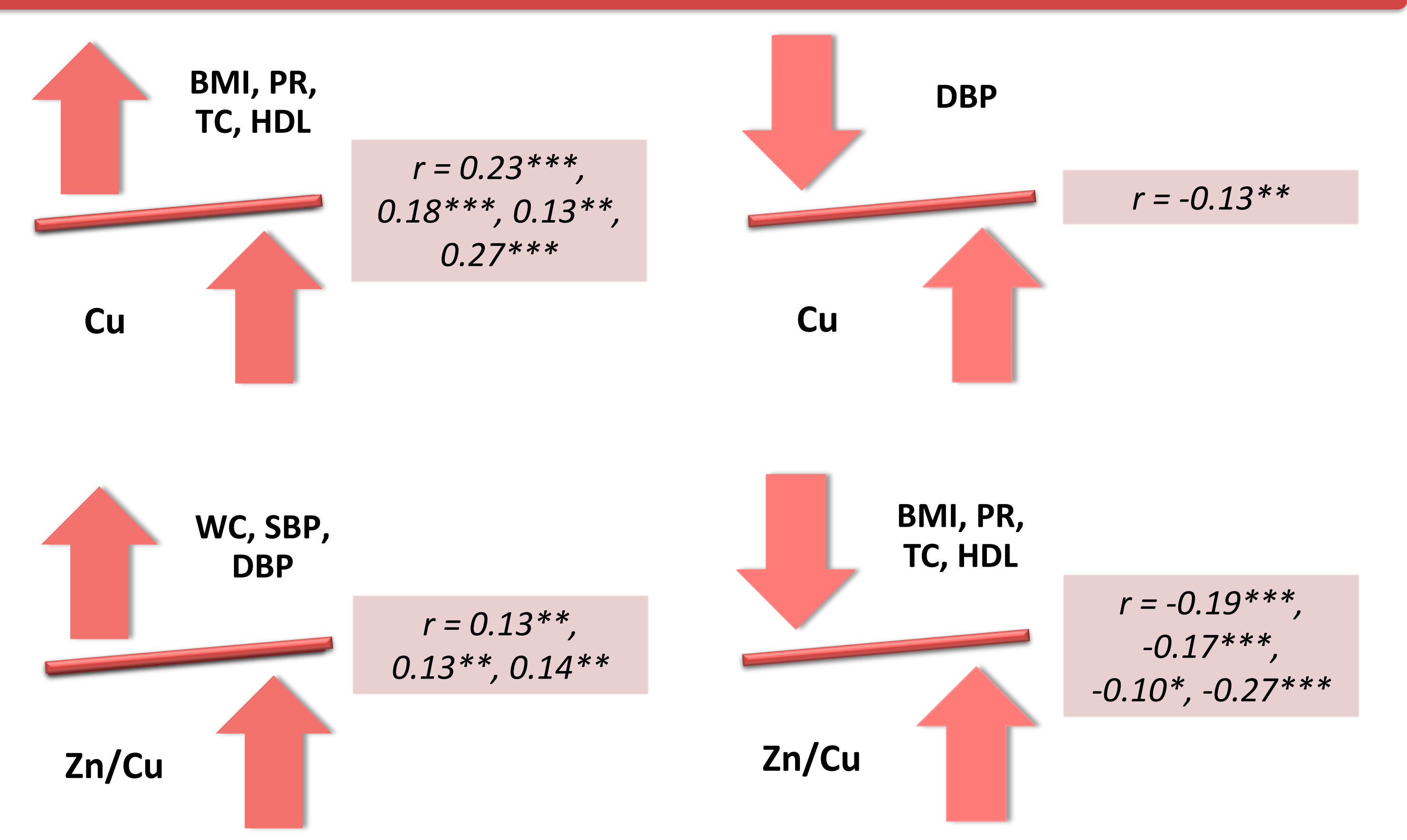

$p>0.01 *, 0.01 \geq p>0.001^{* *}, p \leq 0.001 * * *$ Zn was not strongly correlated with CMR factors (p-value>0.01) (figure 2). Moreover, Zn was not significantly associated with any CMR factors while Cu was negatively associated with high DBP and HDL. Zn/Cu ratio was only significantly negatively associated with high SBP in the second tertile but was positively associated with low HDL in the third tertile.
RESULTS CONT.

\section{Figure 3: Association between serum $\mathrm{Cu}$ and $\mathrm{Zn} / \mathrm{Cu}$ and MetS}
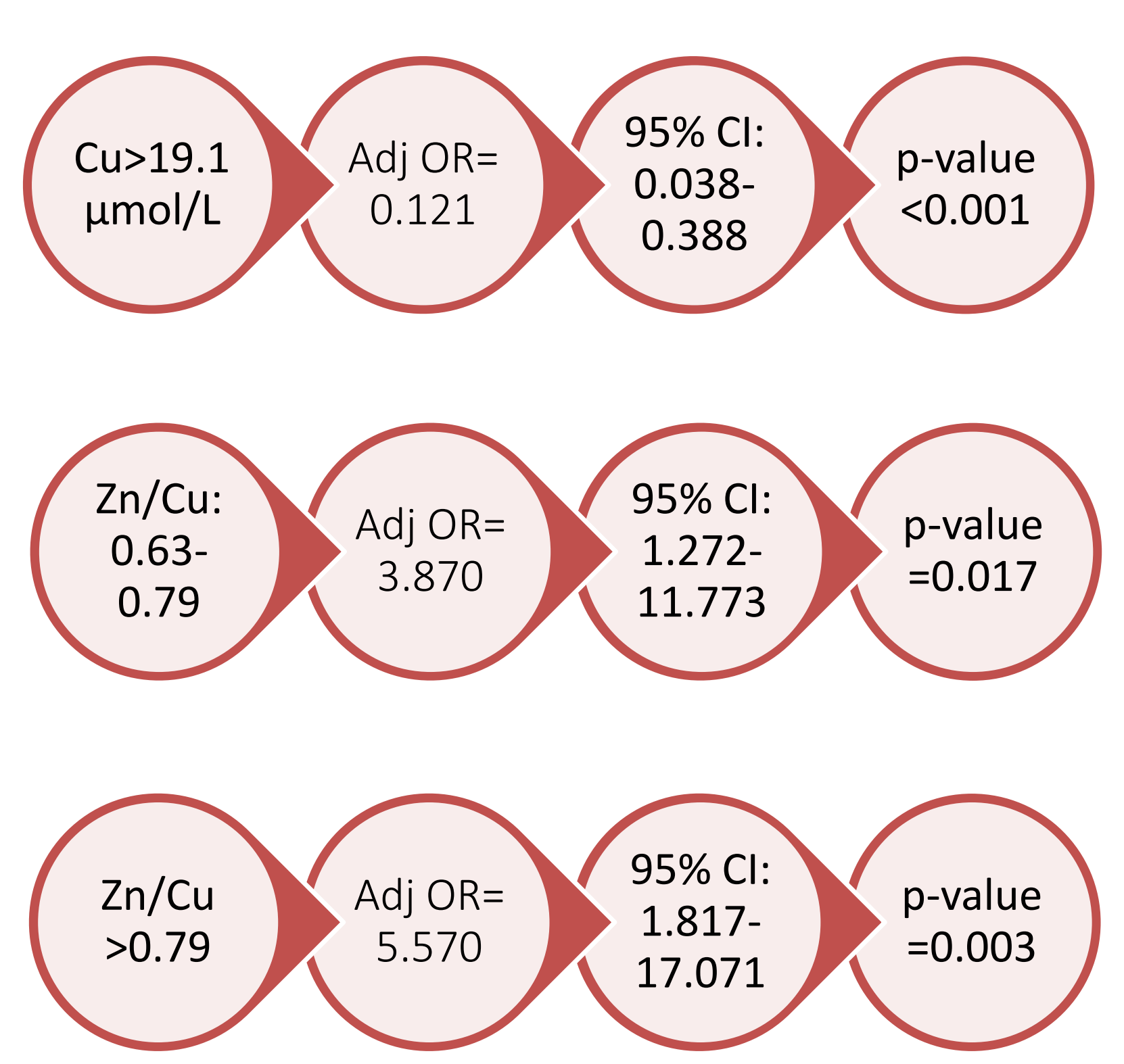

$\mathrm{Zn}$ was not associated with MetS (figure 3). Furthermore, the highest $\mathrm{Cu}$ tertile was significantly associated with low rate of MetS. However, MetS rate increased by more than 5.5 folds with the increase in $\mathrm{Zn} / \mathrm{Cu}$ ratio in $\mathrm{T} 3$.

There were no differences observed in $\mathrm{Zn}, \mathrm{Cu}$ levels and $\mathrm{Zn} / \mathrm{Cu}$ ratio between participants with and without MetS (results not shown).

\section{CONCLUSION}

In conclusion, we did not report any association between serum $\mathrm{Zn}$ and CMR factors or MetS. Furthermore, high serum $\mathrm{Cu},>15.8 \mu \mathrm{mol} / \mathrm{L}$, had a protective effect on DBP, HDL and MetS. Serum Zn/Cu ratio was found to protect against high SBP only in the medium serum levels 0.63-0.79 $\mathrm{mol} / \mathrm{L})$, however serum $\mathrm{Zn} / \mathrm{Cu}$ ratio $>0.79 \mu \mathrm{mol} / \mathrm{L}$ increased the risk of having low HDL. Also, $\mathrm{Zn} / \mathrm{Cu}$ ratio $>0.63 \mu \mathrm{mol} / \mathrm{L}$ increased the risk of Mets.

\section{LIMITATIONS}

first and most important, the study design, which is cross sectional, fails to conclude a causation between the minerals and cardiometabolic markers. Second, the sample size might be too small to represent the population being studied.

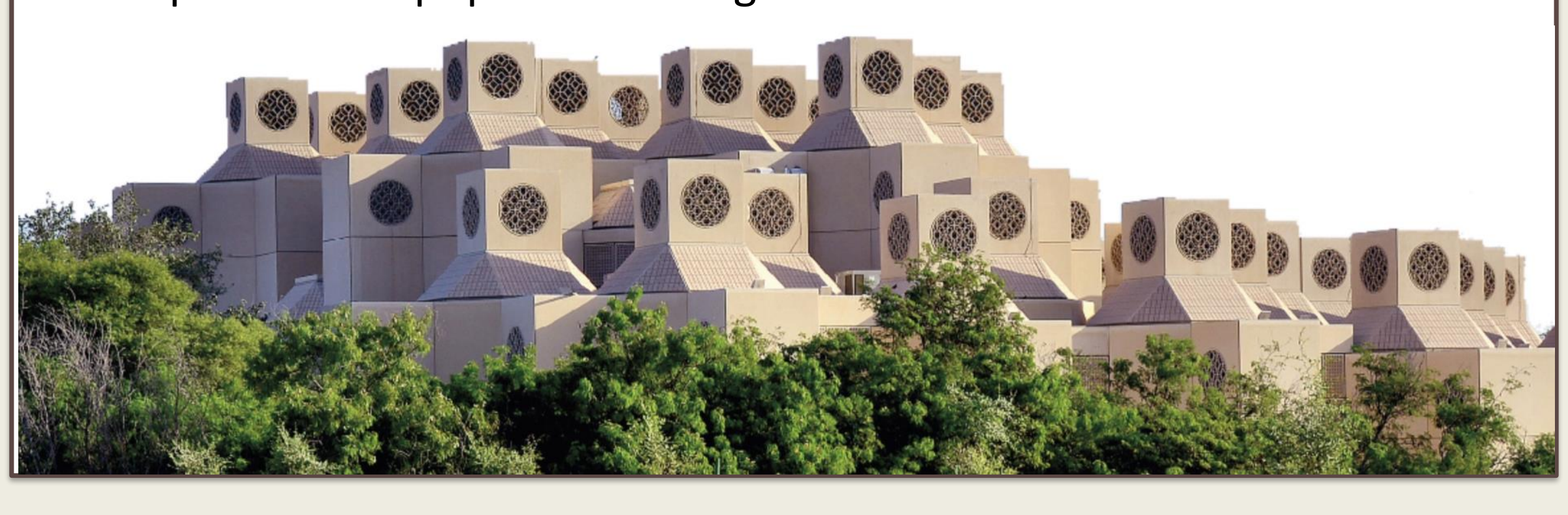

\section{REFERENCES}

1. Knez M, Pantovic A, Zekovic M, Pavlovic Z, Glibetic M, Zec M. Is There a Link between Zinc Intake and Status with Plasma Fatty Acid Profile and Desaturase Activities in Dyslipidemic Subjects? Nutrients 2019; 12(1).

2. Gonoodi K, Moslem A, Darroudi S, et al. Serum and dietary zinc and copper in Iranian girls. Clin Biochem 2018; 54: 25-31

3. Song X, Wang W, Li Z, Zhang D. Association between Serum Copper and Serum Lipids in Adults. Ann Nutr Metab 2018; 73(4): 282-9.

4. Sobczak AIS, Stefanowicz F, Pitt SJ, Ajjan RA, Stewart AJ. Total plasma magnesium, zinc, copper and selenium concentrations in type-I and type-II diabetes. Biometals 2019; 32(1): 123-38.

5. Yao J, Hu P, Zhang D. Associations Between Copper and Zinc and Risk of Hypertension in US Adults. Biol Trace Elem Res 2018; 186(2): 346-53.

6. Bastola MM, Locatis C, Maisiak R, Fontelo P. Selenium, copper, zinc and hypertension: an analysis of the National Health and Nutrition Examination Survey (2011-2016). BMC Cardiovasc Disord 2020; 20(1):

Darroudi S, Saberi-Karimian M, Tayefi M, et al. Association Between Hypertension in Healthy Participants and Zinc and Copper Status: a Population-Based Study. Biol Trace Elem Res 2019; 190(1): 38-44.

\begin{tabular}{|c|c|c|c|c|}
\hline $\begin{array}{l}\text { Multiple linear } \\
\text { regression was } \\
\text { performed to } \\
\text { determine the } \\
\text { relationship } \\
\text { between } \\
\text { mineral } \\
\text { indicators and } \\
\text { CMR }\end{array}$ & $\begin{array}{l}\text { Odds ratio and } \\
95 \% \text { confidence } \\
\text { intervals were } \\
\text { determined }\end{array}$ & $\begin{array}{l}\text { The regression } \\
\text { model was } \\
\text { adjusted for } \\
\text { gender, age, } \\
\text { BMI, and } \\
\text { physical } \\
\text { activity }\end{array}$ & $\begin{array}{l}\text { Partial } \\
\text { correlation to } \\
\text { elucidate the } \\
\text { association } \\
\text { between trace } \\
\text { minerals and } \\
\text { CMR factors }\end{array}$ & $\begin{array}{l}\text { MetS: } 3 / 5 \text { of } \\
\text { the following: } \\
\text { hyperglycemia } \\
\text { or on DM } \\
\text { treatment, high } \\
\text { BP or on HTN } \\
\text { drugs, high TG, } \\
\text { low HDL, and } \\
\text { central obesity }\end{array}$ \\
\hline
\end{tabular}

\section{ACKNOWLEDGEMENTS}

The authors thank Qatar Biobank for providing samples and data that supported the study. This study was supported by grant QUST-2-CHS2020-16 from Qatar University Research Support Office. 